\title{
Anicemycin, a New Inhibitor of Anchorage-independent Growth of Tumor Cells from Streptomyces sp. TP-A0648
}

\author{
Yasuhiro Igarashi, Koushirou Ootsu, Hiroyasu Onaka, Tsuyoshi Fujita, \\ Yoshimasa Uehara, Tamotsu Furumai
}

Received: January 20, 2005 / Accepted: April 28, 2005

(C) Japan Antibiotics Research Association

\begin{abstract}
The anchorage-independence of cells is closely related to their tumorigenicity. In the screening of inhibitors of anchorage-independent growth of tumor cells, anicemycin was isolated from the fermentation broth of an actinomycete strain TP-A0648. The producing strain was isolated from a leaf of Aucuba japonica collected in Toyama, Japan and identified as Streptomyces sp. based on the taxonomic data. The structure of anicemycin was elucidated as a new analog of spicamycin by NMR and MS analysis. Anicemycin inhibited the anchorage-independent growth of the human ovary cancer SKOV-3 cells with an $\mathrm{IC}_{50}$ of $0.015 \mu \mathrm{M}$ about three times more potently than their anchorage-dependent growth.
\end{abstract}

Keywords anicemycin, anchorage-independent growth, cytotoxic, spicamycin, Streptomyces

\section{Introduction}

Most of the previously developed antitumor agents act mainly on the nucleic acid biosynthesis, DNA or microtubules and therefore these agents show cytotoxicity to normal tissues with significant adverse effects. Recent researches on the mechanism of cancer have been disclosing that a number of oncogenes are involved in tumorigenesis and many of these gene products are functioning as signal transduction molecules. The agents that inhibit the signal transduction of oncogenes are

Y. Igarashi (Corresponding author), K. Ootsu, H. Onaka, T. Furumai: Biotechnology Research Center, Toyama Prefectural University, 5180 Kurokawa, Kosugi, Imizu, Toyama 939-0398, Japan, E-mail: yas@pu-toyama.ac.jp expected to become selective and safe anticancer drugs [1].

The normal cells derived from epithelial and endothelial cells can proliferate only when they attach to the firm substrate. When these cells detach from the substrate and lose contact with the matrix, they die in an apoptotic process termed 'anoikis'. On the other hand, cancer cells usually have developed resistance to anoikis and show growth ability without the firm substrate attachment, namely the anchorage-independence. Cell viability under anchorage-dependent conditions is regulated by integrin signal transduction through its interaction with the extracellular matrix. Various oncogenes expressed in transformed and cancer cells cause constitutive activation of the integrin signaling pathway which results in anoikis resistance $[2,3]$.

In our screening program of new antitumor compounds from microbial secondary metabolites, anicemycin (Fig. 1) was isolated as an inhibitor of anchorage-independent growth from Streptomyces sp. TP-A0648. In this paper, we describe the fermentation, isolation, structure and biological activity of anicemycin.

\section{Materials and Methods}

\section{General Experimental Procedures}

NMR experiments were performed on a JEOL JNM-LA400 NMR spectrometer. The MS spectra were measured on a JEOL JMS-HX110A spectrometer. UV spectra were
T. Fujita: Suntory Institute for Bioorganic Research, 1-1-1 Wakayamadai, Shimamoto, Mishima, Osaka 618-8503, Japan

Y. Uehara: National Institute of Infectious Diseases, 1-23-1 Toyama, Shinjuku-ku, Tokyo 162-8640, Japan 

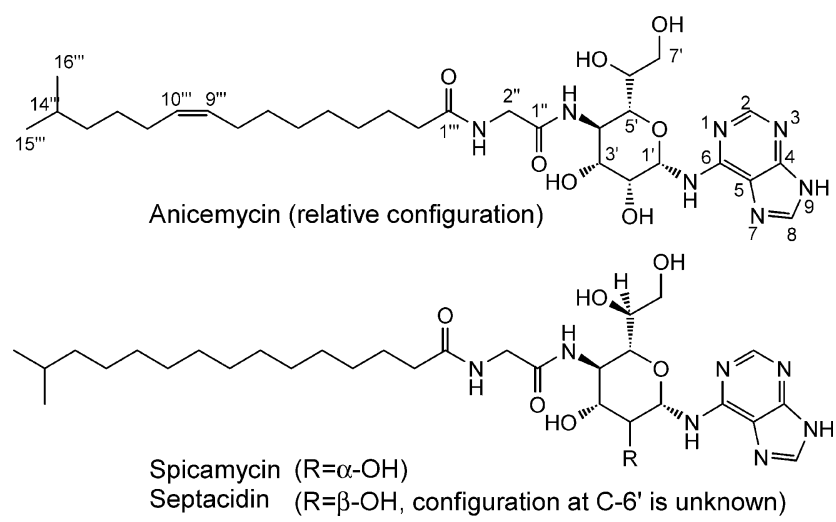

Fig. 1 Structures of anicemycin and related compounds.

recorded on a Hitachi U-3210 spectrophotometer. IR spectrum was recorded on a Shimadzu FT-IR-300 spectrophotometer. Optical rotation was measured on a JASCO DIP-1030. Melting point is not corrected.

\section{The Producing Strain}

The actinomycete strain TP-A0648 was isolated from a leaf of Aucuba japonica Thunb collected in Toyama prefecture, Japan. Isolation procedure was reported previously [4]. A pure culture of strain TP-A0648 was maintained at $23^{\circ} \mathrm{C}$ for laboratory use as a slant on Bennett's agar. It was also preserved in $20 \%$ glycerol at $-80^{\circ} \mathrm{C}$.

\section{Fermentation}

A loopful of a mature slant culture of Streptomyces sp. TPA0648 was inoculated into 500-ml K-1 flasks containing $100 \mathrm{ml}$ of the seed medium consisting of soluble starch $1 \%$, glucose $0.5 \%$, NZ-case (Humco Scheffield Chemical Co.) $0.3 \%$, yeast extract (Difco Laboratories) $0.2 \%$, tryptone (Difco Laboratories) $0.5 \%, \mathrm{~K}_{2} \mathrm{HPO}_{4} 0.1 \%, \mathrm{MgSO}_{4} \cdot 7 \mathrm{H}_{2} \mathrm{O}$ $0.05 \%$ and $\mathrm{CaCO}_{3} 0.3 \%(\mathrm{pH} 7.0)$. The flask was incubated at $30^{\circ} \mathrm{C}$ for 4 days on a rotary shaker $(200 \mathrm{rpm})$. Three-ml aliquots of the seed culture were transferred into a thousand $500-\mathrm{ml} \mathrm{K}-1$ flasks each containing $100 \mathrm{ml}$ of the production medium consisting of corn steep liquor 2\% (Wako Pure Chemical), maltose $4.5 \%$ and HP-20 (Mitsubishi Chemical Co.) $1.0 \%$ ( $\mathrm{pH} 7$ ). Fermentation was carried out for 3 days at $30^{\circ} \mathrm{C}$ on a rotary shaker $(200 \mathrm{rpm})$.

\section{Extraction and Isolation}

The fermented whole broth (100 liters) was extracted with EtOAc (100 liters) with stirring the whole mixture vigorously. The organic layer was separated and concentrated in vacuo to give an oily residue $(8.5 \mathrm{~g})$. The residue was chromatographed on a silica gel column $(170 \mathrm{~g})$ with $\mathrm{CHCl}_{3}-\mathrm{MeOH}(10: 1 \sim 1: 1)$. The active

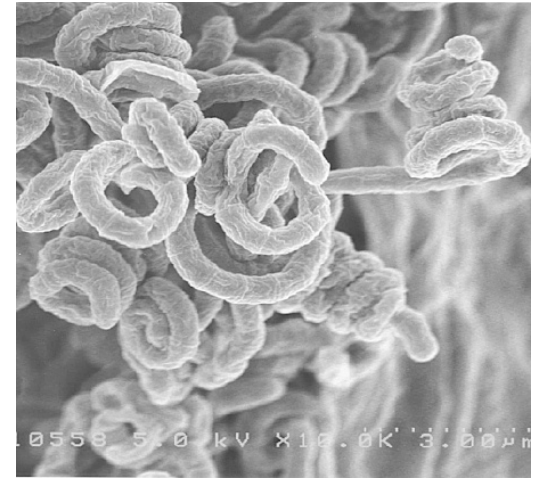

Fig. 2 Scanning electron micrograph of Streptomyces sp. TP-A0648.

fractions $(2: 1 \sim 1: 1)$ were combined and concentrated in vacuo to give brownish solid $(750 \mathrm{mg})$. The solid was further purified by preparative HPLC. The ODS column $\left(300 \times 19 \mathrm{~mm}\right.$, i.d., $7 \mu \mathrm{m}$, XTerra ${ }^{\mathrm{TM}} \mathrm{RP} 18$, Waters) was eluted with $40 \% \mathrm{CH}_{3} \mathrm{CN}$ in $10 \mathrm{mM} \mathrm{NH}_{4} \mathrm{HCO}_{3}(\mathrm{pH} 8)$ and the fraction of anicemycin was collected. The fraction was concentrated in vacuo and the remaining aqueous solution was lyophilized twice to yield anicemycin $(3.3 \mathrm{mg})$.

\section{Biological Assay}

The inhibition of anchorage-independent cell growth was measured against human ovarian cancer SKOV-3 and colon cancer DLD-1 cells as previously described [5]. Briefly, SKOV-3 or DLD-1 cells were grown in Dulbecco's modified Eagle's medium supplemented with $10 \%$ fetal bovine serum and $100 \mu \mathrm{g} / \mathrm{ml}$ kanamycin at $37^{\circ} \mathrm{C}$ with $5 \%$ $\mathrm{CO}_{2}$. The exponentially growing cells were trypsinized and resuspended in fresh medium and then were inoculated onto polyHEMA-coated (suspension culture) or uncoated (attached culture) plates. The cell growth was determined using MTT.

\section{Results and Discussion}

\section{Taxonomy of the Producing Strain}

Streptomyces sp. TP-A0648 was isolated from a leaf of Aucuba japonica Thunb collected in Toyama prefecture, Japan. Taxonomic characteristics of strain TP-A0648 were determined by cultivation on various media described by Shirling and Gottlieb [6], Waksman [7] and Arai [8]. By scanning electron microscope, spore chains are Spirales, and the spore surface is smooth (Fig. 2). The aerial mass color is white to gray and the color of reverse side is pale yellow to dark gray. Diffusible pigments were not formed (Table 1). 
Table 1 Cultural characteristics of strain TP-A0648

\begin{tabular}{|c|c|c|c|c|}
\hline Medium & Aerial mycelium & Reverse side & $\begin{array}{l}\text { Diffusible } \\
\text { pigment }\end{array}$ & Growth \\
\hline $\begin{array}{l}\text { Yeast extract - malt extract agar } \\
\text { (ISP med. 2) }\end{array}$ & Medium gray (406) & Dark gray (421) & None & Good \\
\hline Oatmeal agar (ISP med. 3) & White (388) & Pale yellow (128) & None & Standard \\
\hline Inorganic salts - starch agar (ISP med. 4) & Light bluish gray (404) & Brownish gray (428) & None & Good \\
\hline Glycerol asparagine agar (ISP med. 5) & Medium gray (406) & Dark olive gray (420) & None & Good \\
\hline Tyrosine agar (ISP med. 7) & Olive gray (410) & Dark gray (417) & None & Good \\
\hline Pridham - Gottlieb agar (ISP med. 9) & Yellowish white (389) & Yellowish white (393) & None & Poor \\
\hline
\end{tabular}

The optimum temperature for strain growth is $32 \sim 33^{\circ} \mathrm{C}$. The strain does not grow below $14^{\circ} \mathrm{C}$ or above $37^{\circ} \mathrm{C}$. Strain TP-A0648 utilizes D-glucose, D-fructose, inositol, D-xylose for growth but does not utilize L-rhamnose, D-mannitol, Draffinose and sucrose [6]. Whole cell hydrolysates contain LL-diaminopimelic acid, glucose, mannose, xylose and ribose $[9,10]$. Sequence data of the full length $16 \mathrm{~S}$ rDNA [11] indicates $97.42 \%$ identity to Streptomyces thermoviolaceus. On the basis of these morphological and chemical characteristics, the strain TP-A0648 was identified as Streptomyces sp.

\section{Structure Determination of Anicemycin}

Anicemycin was obtained as a white powder with the melting point of $200^{\circ} \mathrm{C}$ (decomposition). The IR spectrum indicated the presence of an amide $\left(1625 \mathrm{~cm}^{-1}\right)$ and hydroxyl $\left(3300 \mathrm{~cm}^{-1}\right)$ groups. The UV-vis spectrum of anicemycin $\left[\lambda_{\max }(\varepsilon) 205(22,800), 264(13,230)\right.$ in $\left.\mathrm{MeOH}\right]$ showed a high similarity to that of spicamycin, suggesting the presence of an adenine-like chromophore. The molecular formula was determined as $\mathrm{C}_{30} \mathrm{H}_{49} \mathrm{~N}_{7} \mathrm{O}_{7}$ on the basis of the high resolution FABMS which gave a $[\mathrm{M}+\mathrm{H}]^{+}$ ion at $m / z 620.3776\left(\Delta+0.4 \mathrm{mmu}\right.$; calcd for $\left.\mathrm{C}_{30} \mathrm{H}_{50} \mathrm{~N}_{7} \mathrm{O}_{7}\right)$ and the NMR data.

The aromatic protons were observed at $\delta 8.07$ (s) and 8.25 (s). The carbon signals due to the adenine moiety were not observed in the ${ }^{13} \mathrm{C}$ NMR spectrum except for the peak at $\delta 153.0$, but the remaining carbons could be assigned by the analysis of HMQC and HMBC spectra. The HMQC spectrum correlated the proton signals at $\delta 8.25$ and 8.07 to carbon signals at $\delta 153.0$ and 142.5 , respectively. HMBC correlations were observed from the proton at $\delta 8.25$ to the carbons at $\delta 152.4$ and 154.2 and from the proton at $\delta 8.07$ to the carbons at $\delta 119.0$ and 152.4 .

The anomeric proton signal was observed at $\delta 5.63$, five methine signals at $\delta 4.13\left(\mathrm{H}-4^{\prime}\right), 3.99\left(\mathrm{H}-2^{\prime}\right), 3.75\left(\mathrm{H}-3^{\prime}\right)$, $3.74\left(\mathrm{H}-6^{\prime}\right)$ and $3.68\left(\mathrm{H}-5^{\prime}\right)$, and methylene signals at $\delta$
Table 2 Physico-chemical properties of anicemycin

$\begin{array}{ll}\text { Appearance } & \text { White powder } \\ \text { Melting point } & >200^{\circ} \mathrm{C}(\mathrm{dec}) \\ {[\alpha]_{D}^{20}} & +19.2(\mathrm{c} 0.17, \text { methanol) } \\ \text { HRFAB-MS } & \text { Found: } 620.3776[\mathrm{M}+\mathrm{H}]^{+} \\ & \text {Calcd: } 620.3772\left(\text { for } \mathrm{C}_{30} \mathrm{H}_{50} \mathrm{~N}_{7} \mathrm{O}_{7}\right) \\ \text { Molecular formula } & \mathrm{C}_{30} \mathrm{H}_{49} \mathrm{~N}_{7} \mathrm{O}_{7} \\ \text { UV } \lambda_{\max }^{\operatorname{MeOH}} \mathrm{nm}(\varepsilon) & 205(22,800), 264(13,230) \\ \text { IR } v_{\max }\left(\mathrm{cm}^{-1}\right) & 3300,1625\end{array}$

3.75 and 3.64. Connectivities between these signals were confirmed by DQF-COSY and HMBC experiments. H-4' signal was long-range coupled to the carbonyl carbon at $\delta$ 172.5. The configuration of the sugar moiety was confirmed, based on the coupling constants $\left(J_{3^{\prime}, 4^{\prime}}=J_{4^{\prime}, 5^{\prime}}=\right.$ $10 \mathrm{~Hz}, J_{2^{\prime}, 3^{\prime}}=2 \mathrm{~Hz}$ ), except for the C-6' stereochemistry (Fig. 3). The axial configuration of the anomoric proton $\mathrm{H}-$ $1^{\prime}$ was confirmed by a NOESY correlation between H-1' and $\mathrm{H}-5^{\prime}$ observed in the tetra- $\mathrm{O}$-acetyl derivative which was prepared by the treatment of anicemycin with acetic anhydride in pyridine. The absolute configuration of the sugar moiety is not determined.

Methylene signals of the glycine moiety were observed at $\delta 3.85$ and 3.89. These signals had HMBC correlations with carbonyl carbons at $\delta 177.0\left(\mathrm{C}-1^{\prime \prime \prime}\right)$ and $172.5\left(\mathrm{C}-1^{\prime \prime}\right)$.

The fatty acid moiety was identified as 14-methyl-cis-9pentadecenoate based on the NMR analysis. The DQFCOSY spectrum showed a coupling of the methyl signal at $\delta 0.87(6 \mathrm{H}, \mathrm{d}, J=6.6 \mathrm{~Hz})$ to a methine proton at $\delta 1.52$, which, in turn, was coupled to a methylene group at $\delta 1.19$, indicating the presence of an iso-butyl group. The signal at $\delta 1.19$ showed a ${ }^{1} \mathrm{H}-{ }^{1} \mathrm{H}$ correlation to another methylene at $\delta 1.35$ and an HMBC correlation to a methylene carbon $\left(\delta_{\mathrm{C}} 28.7, \delta_{\mathrm{H}} 2.02\right) .{ }^{1} \mathrm{H}-{ }^{1} \mathrm{H}$ correlations were observed 
Table 3 NMR data for anicemycin in $\mathrm{CD}_{3} \mathrm{OD}$

\begin{tabular}{|c|c|c|}
\hline Position & $\delta_{\mathrm{C}}$ & $\delta_{\mathrm{H}}$ (integral, mult., $\mathrm{J} \mathrm{Hz}$ ) \\
\hline \multicolumn{3}{|c|}{ Adenine moiety } \\
\hline 2 & 153.0 & $8.25(1 \mathrm{H}, \mathrm{s})$ \\
\hline 4 & 152.4 & \\
\hline 5 & 119.0 & \\
\hline 6 & 154.2 & \\
\hline 8 & 142.5 & $8.07(1 \mathrm{H}, \mathrm{s})$ \\
\hline \multicolumn{3}{|c|}{ Sugar moiety } \\
\hline $1^{\prime}$ & 80.7 & $5.63(1 \mathrm{H}$, br.s $)$ \\
\hline $2^{\prime}$ & 71.7 & $3.99(1 \mathrm{H}, \mathrm{d}, 2)$ \\
\hline $3^{\prime}$ & 73.8 & $3.75(1 \mathrm{H}, \mathrm{m})$ \\
\hline $4^{\prime}$ & 50.6 & $4.13(1 \mathrm{H}, \mathrm{t}, 10)$ \\
\hline $5^{\prime}$ & 78.8 & $3.68(1 \mathrm{H}, \mathrm{m})$ \\
\hline $6^{\prime}$ & 73.4 & $3.74(1 \mathrm{H}, \mathrm{m})$ \\
\hline \multirow[t]{2}{*}{$7^{\prime}$} & 64.0 & $3.64(1 \mathrm{H}, \mathrm{dd}, 6.8,11.5)$ \\
\hline & & $3.75(1 \mathrm{H}, \mathrm{dd}, 3.2,11.5)$ \\
\hline \multicolumn{3}{|c|}{ Glycine moiety } \\
\hline $1^{\prime \prime}$ & 172.5 & \\
\hline \multirow[t]{2}{*}{$2^{\prime \prime}$} & 43.8 & $3.85(1 \mathrm{H}, \mathrm{d}, 16.6)$ \\
\hline & & $3.89(1 \mathrm{H}, \mathrm{d}, 16.6)$ \\
\hline \multicolumn{3}{|c|}{ Fatty acid moiety } \\
\hline $1^{\prime \prime \prime}$ & 177.0 & \\
\hline $2^{\prime \prime \prime}$ & 36.9 & $2.27(2 \mathrm{H}, \mathrm{t}, 7.8)$ \\
\hline $3^{\prime \prime \prime}$ & 26.8 & $1.63(2 \mathrm{H}, \mathrm{m})$ \\
\hline $4^{\prime \prime \prime}$ & 30.8 & $1.28 \sim 1.38(2 \mathrm{H}, \mathrm{m})$ \\
\hline $5^{\prime \prime \prime}$ & $30.4^{a}$ & $1.28 \sim 1.38(2 \mathrm{H}, \mathrm{m})$ \\
\hline $6^{\prime \prime \prime}$ & $30.4^{\mathrm{a}}$ & $1.28 \sim 1.38(2 \mathrm{H}, \mathrm{m})$ \\
\hline $7^{\prime \prime \prime}$ & $30.2^{a}$ & $1.28 \sim 1.38(2 \mathrm{H}, \mathrm{m})$ \\
\hline $8^{\prime \prime \prime}$ & $28.4^{\mathrm{b}}$ & $2.02(2 \mathrm{H}, \mathrm{m})$ \\
\hline 9"' & $130.8^{c}$ & $5.34(1 \mathrm{H}, \mathrm{m})$ \\
\hline $10^{\prime \prime \prime}$ & $130.9^{c}$ & $5.34(1 \mathrm{H}, \mathrm{m})$ \\
\hline $11^{\prime \prime \prime}$ & $28.7^{\mathrm{b}}$ & $2.02(2 \mathrm{H}, \mathrm{m})$ \\
\hline $12^{\prime \prime \prime}$ & $28.1^{\mathrm{a}}$ & $1.35(2 \mathrm{H}, \mathrm{m})$ \\
\hline $13^{\prime \prime \prime}$ & 39.8 & $1.19(2 \mathrm{H}, \mathrm{m})$ \\
\hline $14^{\prime \prime \prime}$ & 29.1 & $1.52(1 \mathrm{H}, \mathrm{m})$ \\
\hline $15^{\prime \prime \prime}$ & 23.0 & $0.87(3 \mathrm{H}, \mathrm{d}, 6.8)$ \\
\hline $16^{\prime \prime \prime}$ & 23.0 & $0.87(3 \mathrm{H}, \mathrm{d}, 6.8)$ \\
\hline
\end{tabular}

between the signal at $\delta 1.38$ and 1.63 , and $\delta 1.63$ and 2.27 in the DQF-COSY spectrum, and a long-range coupling was detected from the proton at $\delta 2.27$ to the carbonyl carbon at $\delta 177.0$. The olefinic protons at $\delta 5.34(2 \mathrm{H}, \mathrm{m})$ were coupled to the methylene signals at $\delta 2.02\left(4 \mathrm{H}, \mathrm{m}, \delta_{\mathrm{C}}\right.$ $\left.28.7, \delta_{\mathrm{C}} 28.4\right)$ and the HMBC correlation was detected from the proton signal at $\delta 1.19$ to the carbon at $\delta 28.7$. The geometry of the olefin was determined to be $Z$ by comparing with the ${ }^{13} \mathrm{C}$ NMR data of unsaturated fatty acids. For example, the allylic carbons of elaidic acid (trans-9-octadecenoic acid) appear at $\delta 32.5$ and 32.6 whereas those of oleic acid (cis-9-octadecenoic acid) appear at $\delta 27.1$ and 27.2 in $\mathrm{CDCl}_{3}$ [12]. This chemical shift difference is rationalized by the electron repulsion between two cis-allylic methylene groups which induces the higher electron density on the allylic carbons in oleic acid than in elaidic acid. In case of anicemycin, two allylic carbons were observed around $\delta$ 28 29 that were characteristic chemical shifts observed in cis-unsaturated fatty acids.

The structure of anicemycin was thus established as depicted in Fig. 1. Anicemycin consists of four partial structures, adenine, aminosugar, glycine, and fatty acid, and is structurally related to spicamycin [13] and septacidin [14], antitumor antibiotics from Streptomyces. The sugar moiety of spicamycin and septacidin has an L-pyranose configuration and their difference lies in the orientation of the hydroxyl group at C-2'. The relative configuration of the pyranose moiety of anicemycin is same with that of spicamycin. Spicamycin was isolated together with several congeners of varying fatty acid chains but none of them contained an unsaturated fatty acid like anicemycin. On the other hand, the production of spicamycin and septacidin by strain TP-A0648 was not detected in the LC-MS analysis.

\section{Biological Activity of anicemycin}

$\mathrm{IC}_{50}$ values of anicemycin against SKOV-3 and DLD- 1 cells under the anchorage-independent condition were 0.015 and $0.029 \mu \mathrm{M}$, respectively, while those under the anchoragedependent condition were 0.045 and $0.068 \mu \mathrm{M}$, respectively. Anicequol is the most selective anchorageindependent growth inhibitor we previously isolated from a fungus [5]. It inhibits the anchorage-independent growth of DLD-1 cells with an $\mathrm{IC}_{50}$ of $1.6 \mu \mathrm{M}$ without showing growth inhibition to the cells under anchorage-dependent condition at the same concentration. In spite of the low selectivity, anicemycin is expected as a lead molecule for anchorage-independent growth inhibitors owing to its quite low $\mathrm{IC}_{50}$ values. Structure-activity relationship studies are in progress to improve the selectivity.

Acknowledgment We are in debt to Ms. N. Saito at National Institute of Infectious Diseases, Japan, for the measurement of scanning electron microscope and Prof. M. Ubukata at the Hokkaido University for a valuable discussion. This study was partly supported by a Grant-in Aid from the Ministry of Education, Science, Sports and Culture of Japan (Y. I.) and the Social Institute Agency Contract Fund of the Japan Health Science Foundation (Y. U.). 


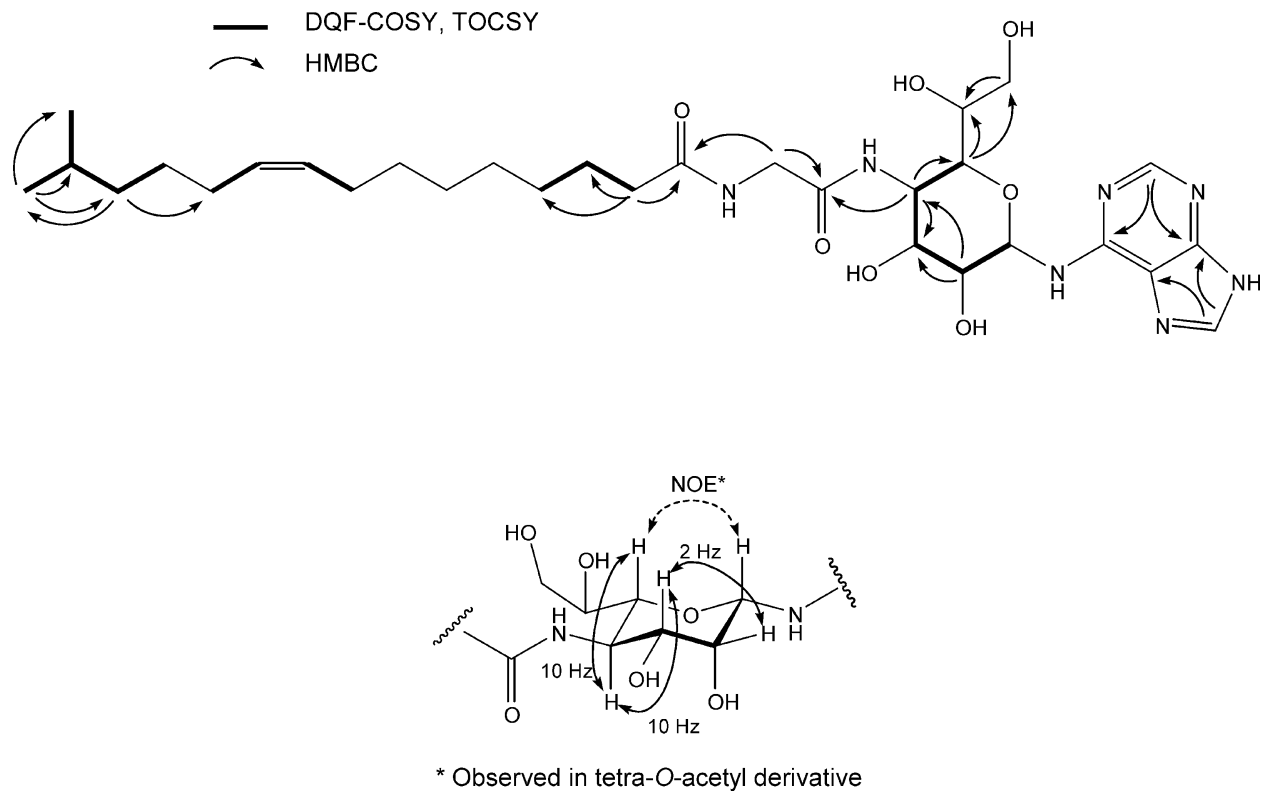

Fig. 3 NMR analysis of anicemycin.

\section{References}

1. Uehara Y. Natural product origins of Hsp90 inhibitors. Curr Cancer Drug Targets 3: 325-330 (2003)

2. Zhan M, Zhao H, Han ZC. Signaling mechanisms of anoikis. Hitol Histopathol 19: 973-983 (2004)

3. Douma S, Van Laar T, Zevenhoven J, Meuwissen R, Van Garderen E, Peeper DS. Suppression of anoikis and induction of metastasis by the neurotrophic receptor TrkB. Nature 430: 1034-1040 (2004)

4. Igarashi Y, Iida T, Sasaki T, Saito N, Yoshida R, Furumai T. Isolation of actinomycetes from live plants and evaluation of antiphytopathogenic activity of their metabolites. Actinomycetol 16: 9-13 (2002)

5. Igarashi Y, Sekine A, Fukazawa H, Uehara Y, Yamaguchi K, Endo Y, Okuda T, Furumai T, Oki T. Anicequol, a novel inhibitor for anchorage-independent growth of tumor cells from Penicillium aurantiogriseum Dierckx TP-F0213. J Antibiot 55: 371-376 (2002)

6. Shirling EB, Gottlieb D. Methods for characterization of Streptomyces species. Intern J Syst Bact 16: 313-340 (1966)

7. Waksman SA. $(E d$.): Classification, identification and description of genera and species. In The Actinomycetes. Vol. II. pp. 328-334. The Williams \& Wilkins Co., Baltimore (1961)
8. Arai T. $(E d$.): In Culture Media for Actinomycetes. The Society for Actinomycetes Japan (1975)

9. Lechevalier HA, Lechevalier MP. A critical evaluation of the genera of aerobic actinomycetes. In The Actinomycetales, Ed., Prauser H. pp. 393-405. Jena, Gustav Fischer Verlag (1970)

10. Staneck JL, Roberts GD. Simplified approach to identification of aerobic actinomycetes by thin-layer chromatography. Appl Microbiol 28: 226-231 (1974)

11. Furumai T, Eto K, Sasaki T, Higuchi H, Onaka H, Saito N, Fujita T, Naoki H, Igarashi Y. TPU-0037-A, B, C and D, novel lydicamycin congeners with anti-MRSA activity from Streptomyces platensis TP-A0598. J Antibiot 55: 873-880 (2002)

12. Pouchert CJ, Behnke J. The Aldrich Library of ${ }^{13} \mathrm{C}$ and ${ }^{1} \mathrm{H}$ FT NMR Spectra. Edition I, Volume I, pp. 782-783, Aldrich Chemical Company, Inc. (1993)

13. Hayakawa Y, Nakagawa M, Kawai H, Tanabe K, Nakayama H, Shimazu A, Seto H, Otake N. Studies on the differentiation inducers of myeloid leukemic cells III. Spicamycin, a new inducer of differentiation of HL-60 human promyelocytic leukemia cells. J Antibiot 36: 934 937 (1983)

14. Acton EM, Ryan KJ, Luetzow AE. Antitumor septacidin analogues. J Med Chem 20: 1362-1370 (1977) 